\title{
LIFE CYCLE, FEEDING AND ADAPTIVE STRATEGY IMPLICATIONS ON THE CO-OCCURRENCE OF Argyrodiaptomus furcatus AND Notodiaptomus iheringi IN LOBO-BROA RESERVOIR (SP, BRAZIL)
}

\author{
RIETZLER, A. C., ${ }^{1}$ MATSUMURA-TUNDISI, T. ${ }^{2}$ and TUNDISI, J. G. ${ }^{2}$ \\ ${ }^{1}$ Departamento de Biologia Geral/ICB, UFMG, Av. Antônio Carlos, 6627, CEP 30270-901, \\ Belo Horizonte, MG, Brazil, e-mail: rietzler@mono.icb.ufmg.br \\ ${ }^{2}$ Instituto Internacional de Ecologia, Rua Bento Carlos, 750, CEP 13560-660, \\ São Carlos, SP, Brazil, e-mail: tmt.iie@iie.com.br; jgt.iie@iie.com.br \\ Correspondence to: Takako Matsumura-Tundisi, Instituto Internacional de Ecologia, Rua Bento Carlos, 750, \\ CEP 13560-660, São Carlos, SP, Brazil, e-mail: tmt.iie@iie.com.br; jgt.iie@iie.com.br \\ Received February 19, 2001 - Accepted August 20, 2001 - Distributed February 28, 2002
}

(With 5 figures)

\begin{abstract}
The population dynamics, life cycle and feeding of Argyrodiaptomus furcatus and Notodiaptomus iheringi, were studied in Broa reservoir from August 1988 to August 1989, period when a replacement of $A$. furcatus by $N$. iheringi was observed. Some abiotic factors such as temperature, dissolved oxygen, $\mathrm{pH}$ and conductivity were measured to characterize the limnological conditions of the reservoir. Also, phytoplankton composition was analyzed and related to the feeding of the two species. Experimental data on developmental time and reproduction of A. furcatus and $N$. iheringi under different temperatures showed that lower temperatures were responsible for density decreasing of both populations in the reservoir during the dry season. Chlorophyta and Chrysophyta smaller than $20 \mu \mathrm{m}$ were the most abundant phytoplankton groups in the reservoir as well as in the gut content of A. furcatus and N. iheringi, representing an important food source for both species. The temporary disappearance of Argyrodiaptomus furcatus, observed between 1988 and 1989 and its replacement by Notodiaptomus iheringi was related to mining activities upstream, modifying the water turbidity, $\mathrm{pH}$ and conductivity. However, the reappearance and maintenance of $A$. furcatus for another ten years and a recent replacement re-incidence indicates that these two calanoids do not coexist in this environment. Adaptive strategies of both species, related to changes in environmental conditions, are discussed. Probably, Argyrodiaptomus furcatus is an indicator of less eutrophic environments, while Notodiaptomus iheringi of more eutrophic systems.
\end{abstract}

Key words: Copepoda Calanoida, life cycle, feeding, adaptive strategy, abiotic factors, shallow reservoir.

\section{RESUMO}

\section{Implicações da estratégia adaptativa, ciclo de vida e alimentação na co-ocorrência de Argyrodiaptomus furcatus e Notodiaptomus iheringi na Represa do Lobo-Broa (SP, Brasil)}

A dinâmica da população, o ciclo de vida e a alimentação de Argyrodiaptomus furcatus e de Notodiaptomus iheringi foram investigados na represa do Broa, durante o período de agosto de 1988 a agosto de 1989, quando houve a substituição da primeira espécie pela segunda. Alguns fatores abióticos, como temperatura, oxigênio dissolvido, $\mathrm{pH}$ e condutividade, foram medidos para caracterizar as condições limnológicas do reservatório. A composição fitoplanctônica também foi analisada para ser relacionada à alimentação das duas espécies. Dados experimentais sobre o tempo de desenvolvimento e a reprodução de $A$. furcatus e $N$. iheringi sob diferentes temperaturas mostraram que baixas temperaturas foram responsáveis pelo decréscimo de ambas as populações durante a estação de seca. Chlorophyta 
e Chrysophyta, grupos de organismos de fitoplâncton menores do que $20 \mu \mathrm{m}$, foram os mais abundantes tanto no reservatório quanto no conteúdo estomacal de A. furcatus e de $N$. iheringi, constituindo importante fonte de alimento para ambas as espécies. O desaparecimento temporário de Argyrodiaptomus furcatus, observado entre 1988 e 1989, e sua substituição por Notodiaptomus iheringi coincide com a atividade mineradora instalada na cabeceira do reservatório nesse período, alterando a turbidez, o pH e a condutividade. Entretanto, o reaparecimento e a manutenção de A. furcatus por mais dez anos, e a recente reincidência da substituição, indicam que essas duas espécies de Calanoida não coexistem nesse ambiente. Estratégias adaptativas de ambas as espécies em relação às condições ambientais são discutidas. Provavelmente, Argyrodiaptomus furcatus seja uma espécie indicadora de ambientes menos eutróficos, enquanto Notodiaptomus iheringi sobrevive bem em sistemas eutróficos com freqüentes florescimentos de cianofíceas.

Palavras-chave: Copepoda Calanoida, estratégia adaptativa, ciclo de vida, alimentação, fatores abióticos, eutrofização.

\section{INTRODUCTION}

Broa reservoir is a small and shallow artificial lake located in the State of São Paulo, Brazil. It has been studied since 1971 and until a few years ago it was considered a reservoir with good water quality, poor in nutrients and organic production (Tundisi \& Matsumura-Tundisi, 1995). Phytoplankton community has been dominated by Chrysophyceae and Chlorophyceae (Rietzler, 1991) and zooplankton community by several species of Rotifera, followed by Cladocera with 8 species and Copepoda, represented by Argyrodiaptomus furcatus (MatsumuraTundisi \& Tundisi, 1976).

However, the increase of human activities, including sand mining, urban growth, tourism, recreation and construction of holyday residences around the reservoir, has promoted the degradation of water quality, and consequently, changes in the biota.

Within this context, the population dynamics, life-cycle and feeding of the copepods Argyrodiaptomus furcatus and Notodiaptomus iheringi were analyzed in order to understand the replacement of the former by the latter and vice-versa, associated with changes in environmental conditions.

\section{MATERIAL AND METHODS}

From the period of August 1988 to August 1989, plankton samples were collected monthly in the region near the dam of the reservoir (Fig. 1) to analyze the copepod populations. Also, daily sampling was carried out in September/October,
1988 and every two days during March and July/ August-1989 in order to analyze the two calanoid populations and the phytoplankton community. At the same time, water samples were collected for "in situ" measurements of abiotic variables (temperature, oxygen, $\mathrm{pH}$ and conductivity).

Experimental data on the developmental time, survival, fecundity and longevity at three temperatures $\left(17,21\right.$ and $\left.26^{\circ} \mathrm{C}\right)$ were obtained for both species of Calanoida. The egg development time was obtained through the indirect method described in Edmondson (1965). The organisms were kept under photoperiod of 12 hours and fed daily with Monoraphidium dybowskii at a concentration of $10^{5}$ cels $\mathrm{ml}^{-1}$.

Gut content analyses of Argyrodiaptomus furcatus and Notodiaptomus iheringi were carried out according to Gannon \& Gannon (1974), with the specimens anesthetized in gas water $(6 \%)$ and fixed in formalin solution (4\%).

\section{RESULTS}

Biotic and abiotic variables of the Broa reservoir

Broa reservoir is a polimictic system with a constant homogenization of water mass. Thus, sometimes, a weak thermocline or even an oxycline may occur during the day. However, it does not remain for a long time.

Table 1 shows the maximum, minimum and mean values of water temperature and dissolved oxygen registered during the daily sampling carried out in three periods of the year. It can be seen that the variation of temperature from surface to bottom was inferior to $2^{\circ} \mathrm{C}$. High values of temperature 
could be observed in March 1989, end of summer, and low values were registered in July/August, 1989, winter period. The oxygen concentration was high from surface to bottom, in the winter. However, low concentrations of oxygen were registered during the summer.

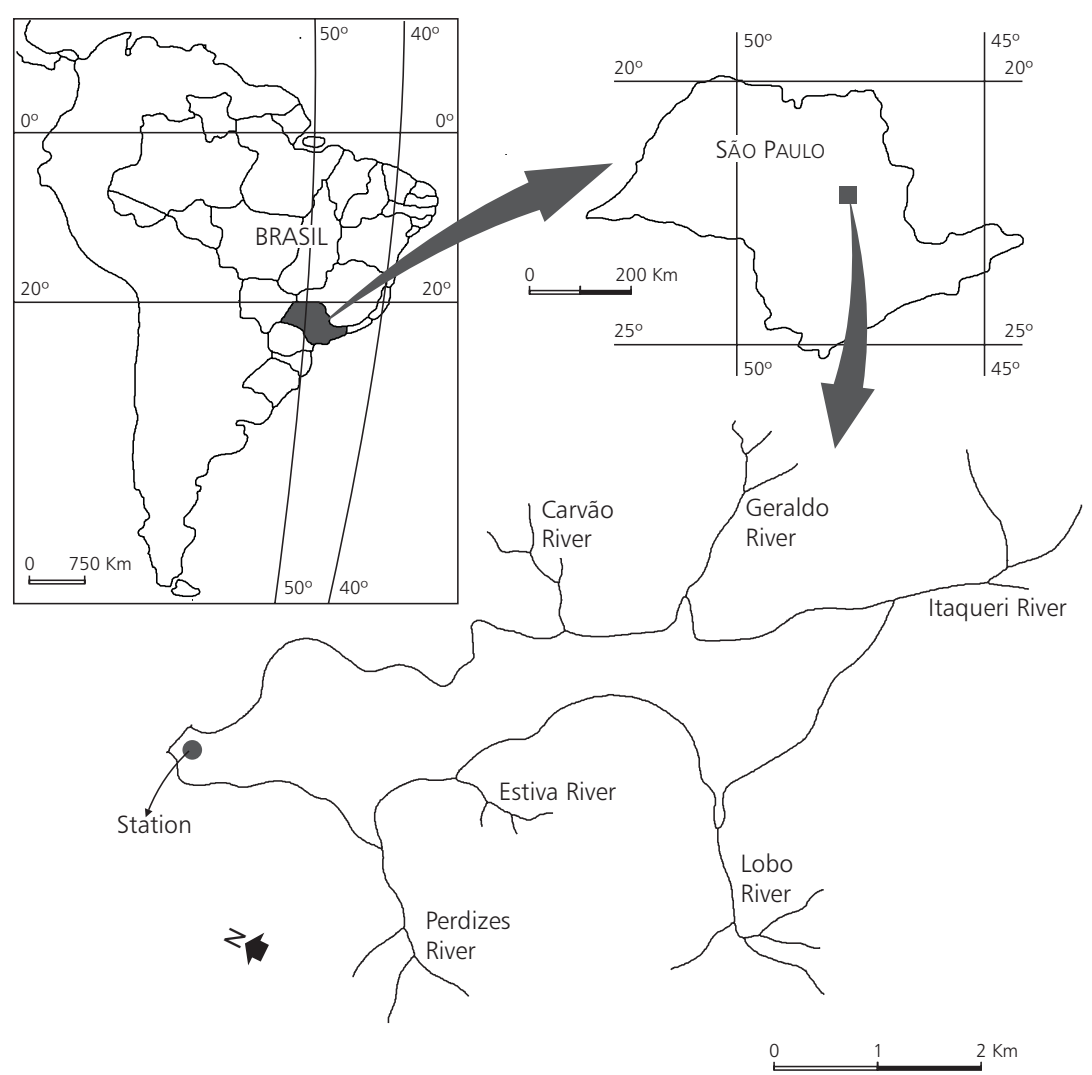

Fig. 1 - Morphology of Lobo (Broa) Reservoir located in São Paulo State, Brazil, and the site of sampling station.

TABLE 1

Values of temperature and dissolved oxygen concentration registered at the surface and the bottom of the reservoir during the sampling periods.

\begin{tabular}{|c|c|c|c|}
\hline \multirow{2}{*}{ Data } & \multirow{2}{*}{ Depth } & Temp. $\left({ }^{\circ} \mathrm{C}\right)$ & $\mathrm{O}_{2}(\mathrm{mg} / \mathrm{L})$ \\
\hline & & Average (Max.-Min.) & Average (Max.-Min.) \\
\hline \multirow{2}{*}{$\begin{array}{c}1988 \\
\text { September, } 15 \text { to October, } 27\end{array}$} & Surface & $22.4(24.8-22.0)$ & $7.69(8.4-6.3)$ \\
\hline & Bottom & $21.1(22.1-19.2)$ & $7.03(8.0-4.7)$ \\
\hline \multirow{2}{*}{$\begin{array}{c}1989 \\
\text { March, } 2 \text { to } 24\end{array}$} & Surface & $26.7(27.7-25.0)$ & $7.08(8.1-5.4)$ \\
\hline & Bottom & $24.8(25.4-24.1)$ & $3.04(5.4-1.2)$ \\
\hline \multirow{2}{*}{$\begin{array}{c}1989 \\
\text { July, } 5 \text { to August, } 4\end{array}$} & Surface & $17.2(19.2-15.7)$ & $9.0(10.1-8.3)$ \\
\hline & Bottom & $16.4(17.9-15.3)$ & $8.21(9.4-7.7)$ \\
\hline
\end{tabular}


Fig. $2(a, b, c)$ shows the frequency of $\mathrm{pH}$ values registered in the reservoir during SeptemberOctober/88, March/89 and July-August/89, respectively.

It is possible to verify that in SeptemberOctober/88 the most frequent values of $\mathrm{pH}$ were between 5.6 and 5.8. In March/89, the most fre- quent $\mathrm{pH}$ values fluctuated at 5.2; 6.0 and 6.4, probably due to the precipitation factor. In July/ August/89, the tendency of the most frequent values of $\mathrm{pH}$ was at a range of 6.1 and 6.3. These values show that a small change in the $\mathrm{pH}$ values of the reservoir occurred from 1988 to 1989, becoming less acid.
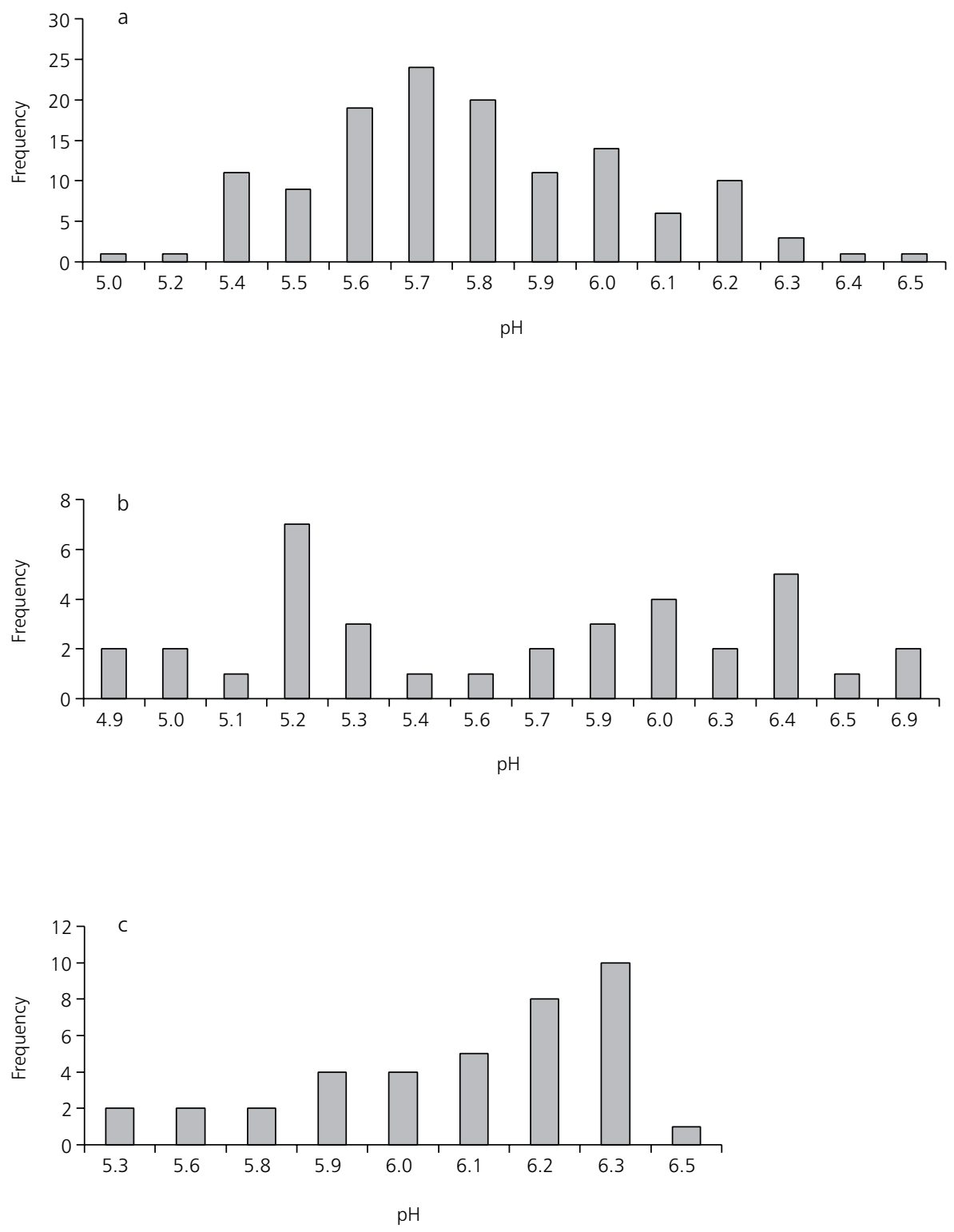

Fig. 2 - Frequency of pH values registered at Broa Reservoir during 15/9/88 to 28/10/88 in daily sampling (a); during $2 / 3 / 89$ to $24 / 3 / 89$ (b); and during $5 / 7 / 89$ to $4 / 8 / 89$ (c) every two days sampling. 
Fig. $3(a, b, c)$ shows the frequency of conductivity values registered during the three periods of study, respectively. In September-October/88, the most frequent values of conductivity varied

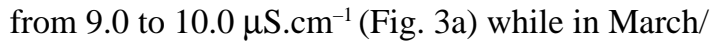
89 (Fig. 3b) and July-August/89 (Fig. 3c) the values ranged from 11.0 to $12.0 \mu \mathrm{S} . \mathrm{cm}^{-1}$.

\section{Phytoplankton composition and variation of Copepoda Calanoida populations}

The composition and abundance of Broa's phytoplankton species is shown in Table 2. The most abundant species of phytoplankton recorded in the three periods of study were Microcystis sp. and Oscillatoria sp. among Cyanophyta; Rhizosolenia eriensis, Aulacoseira spp., and Nitzchia spp. (Chrysophyta); and Cosmarium sp. and Monoraphidium spp. (Chlorophyta).

Among the zooplankton community special attention was given to Copepoda Calanoida, which has been considered the major contributor of secondary organic production of the reservoir (Rocha $\&$ Matsumura-Tundisi, 1984; Matsumura-Tundisi et al., 1989). Argyrodiaptomus furcatus present in the reservoir since 1971 (Matsumura-Tundisi \& Tundisi, 1976; Rocha et al., 1982) remained until 1986, when it was replaced by Notodiaptomus iheringi.
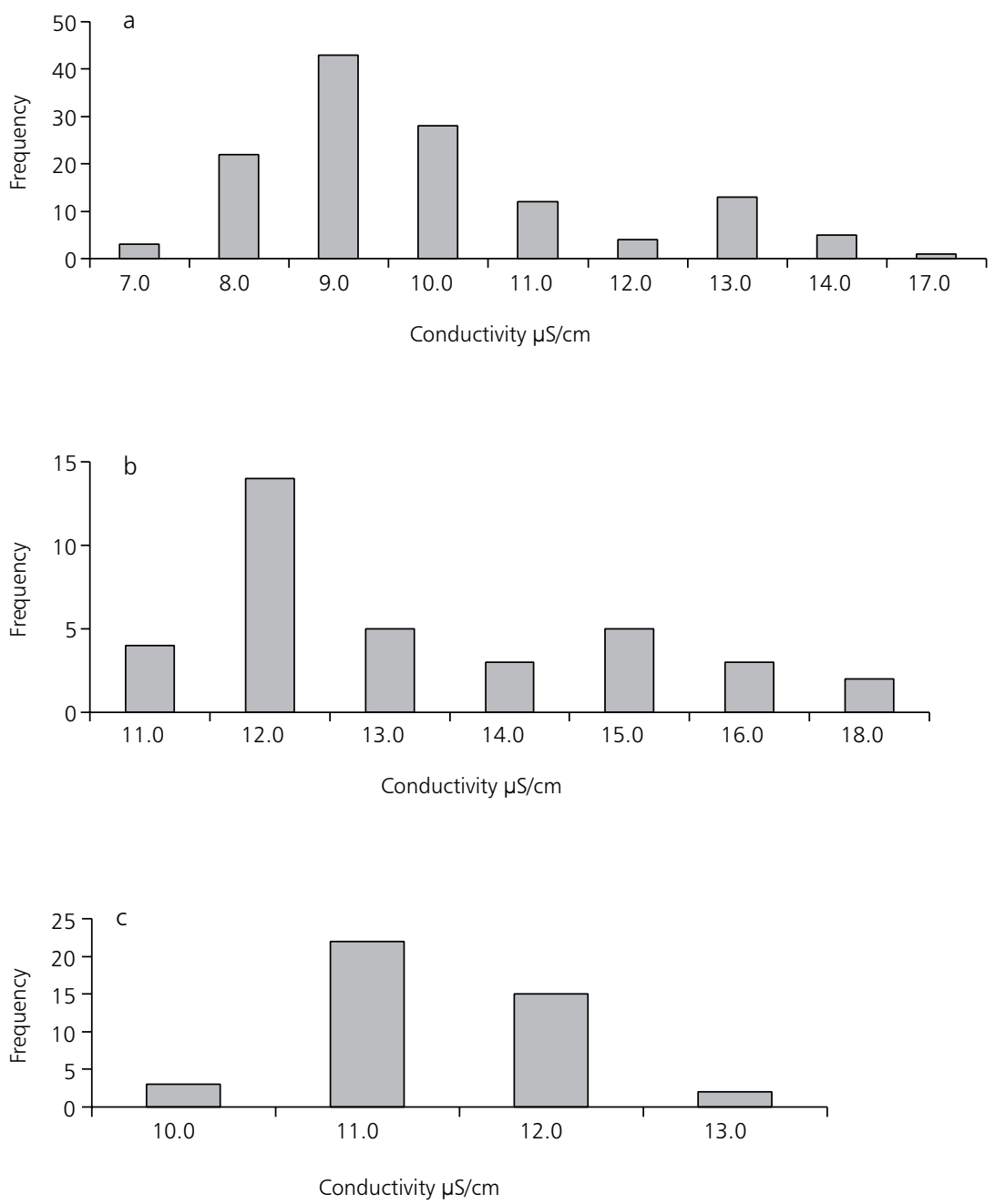

Fig. 3 - Frequency of conductivity values registered at Broa Reservoir during 15/9/88 to 28/10/88 in daily sampling (a); during $2 / 3 / 89$ to $24 / 3 / 89$ (b); and during $5 / 7 / 89$ to $4 / 8 / 89$ (c) sampled every two days. 
TABLE 2

Phytoplankton composition of Broa Reservoir and its abundance during the campaign of 1988-1989.

\begin{tabular}{|l|c|}
\hline Groups/Genera & Abundance \\
\hline Cyanophyta & \\
\hline Anabaena sp. & + \\
\hline Aphanothece sp. & ++ \\
\hline Chroococcus sp. & ++ \\
\hline Merismopedia sp. & +++ \\
\hline Microcystis sp. & +++ \\
\hline Oscillatoria sp. & + \\
\hline Synechocystis sp. & + \\
\hline Pirrophyta & + \\
\hline Peridinium sp. & + \\
\hline Chrysophyta & + \\
\hline Cymbella sp. & ++ \\
\hline Dinobryon sp. & ++ \\
\hline Eunotia sp. & ++ \\
\hline Frustulia sp. & ++ \\
\hline Melosira distans + & ++ \\
\hline Cyclotella sp. & ++ \\
\hline Melosira. italica & ++ \\
\hline Melosira. granulata & + \\
\hline Melosira sp. & ++ \\
\hline Navicula sp. & + \\
\hline Neidium sp. & + \\
\hline Nitzchia spp. & + \\
\hline Penalles & + \\
\hline Pinnularia sp. & + \\
\hline Rhizosolenia eriensis & + \\
\hline Stauroneis sp. & + \\
\hline Surirella sp. & + \\
\hline Tabellaria sp. & + \\
\hline Tetraedriella sp. & + \\
\hline
\end{tabular}

Fig. 4 (a, b and c) shows the variation of adult populations of Argyrodiaptomus furcatus and Notodiaptomus iheringi at the three periods of the year (short sampling intervals) and Fig. 5 shows the monthly variation of these two populations from August 1988 to August 1989. It can be observed that in 1988, the population of Notodiaptomus
TABLE 2 (Continued)

\begin{tabular}{|l|c|}
\hline Groups/Genera & Abundance \\
\hline $\begin{array}{l}\text { Phytoflagelates } \\
\text { (Euglenophyta }+ \\
\text { Chlorophyta) }\end{array}$ & ++ \\
\hline Chlorophyta & \\
\hline Actnotaenium sp. & + \\
\hline $\begin{array}{l}\text { Ankistrodesmus } \text { sp. }+ \\
\text { Monoraphidium } \text { sp. }\end{array}$ & +++ \\
\hline Asterococcus sp. & + \\
\hline Botryococcus sp. & + \\
\hline Chorococcales & + \\
\hline Coelastrum sp. & ++ \\
\hline Cosmarium sp. & +++ \\
\hline Crucigenia sp. & ++ \\
\hline Dictyosphaerium sp. & ++ \\
\hline Elakatothrix sp. & ++ \\
\hline Euastrum sp. & ++ \\
\hline Gloeocystis sp. & ++ \\
\hline Golenkinia sp. & + \\
\hline Kirchneriella sp. & + \\
\hline Oocystis lacustris & + \\
\hline ++++ $10^{7}$ & + \\
\hline Pediastrum sp. & + \\
\hline Quadrigula sp. & + \\
\hline Scenedesmus sp. & + \\
\hline Selenastrum sp. & + \\
\hline Sphaerocystis sp. & + \\
\hline Staurastrum sp. & + \\
\hline Staurodesmus sp. & + \\
\hline Tetraedron caudatum & + \\
\hline Tetrallantos sp. & + \\
\hline Tetrastrum sp. & + \\
\hline++ & + \\
\hline
\end{tabular}

iheringi was present in the reservoir in large densities. However in February 1989 this population started to decrease while the population of Argyrodiaptomus furcatus started to increase. At the end of 1989, there was a complete disappearance of Notodiaptomus iheringi and replaced by Argyrodiaptomus furcatus. 

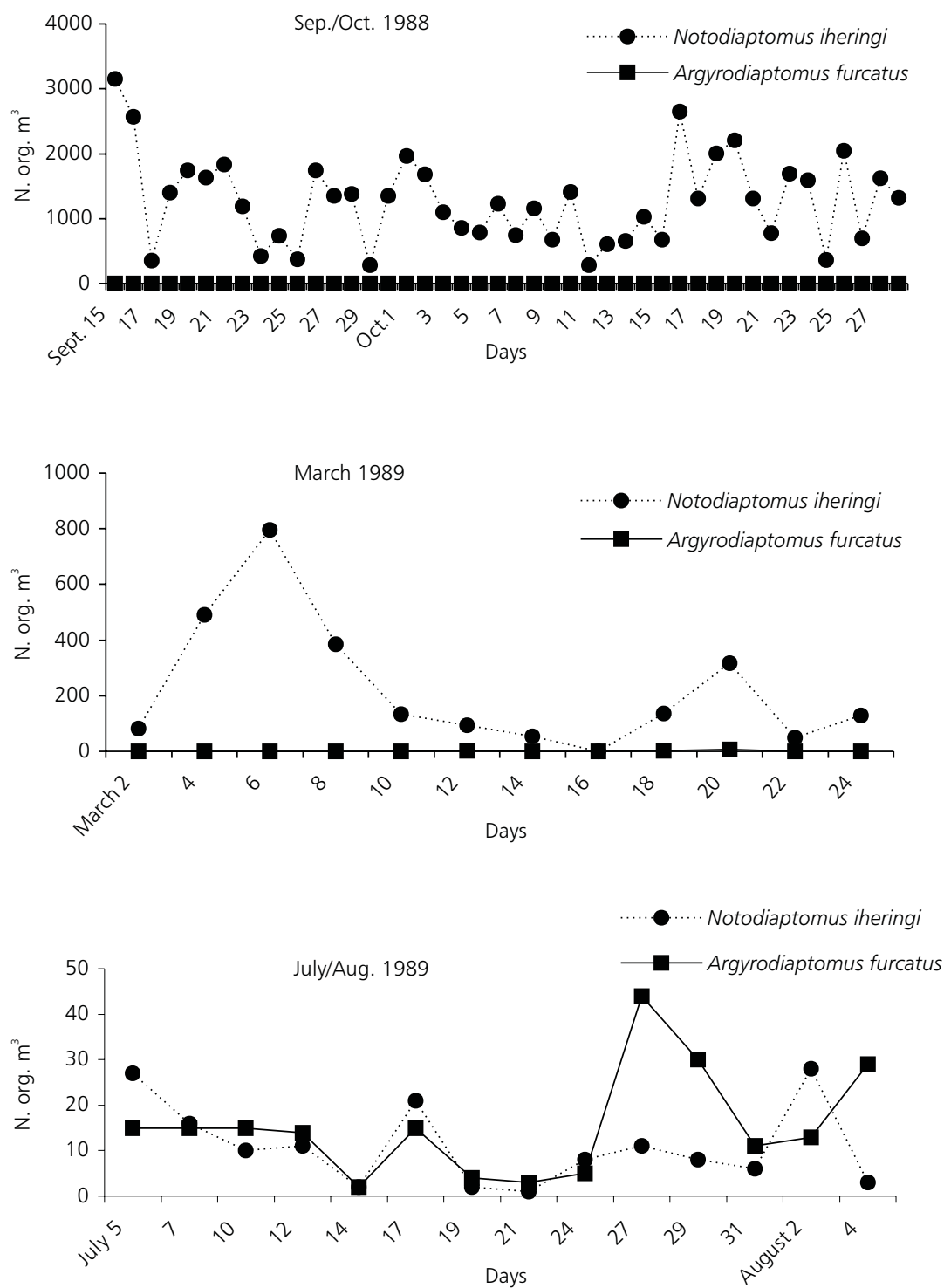

Fig. 4 - Substitution of Notodiaptomus iheringi population from Broa reservoir by Argyrodiaptomus furcatus during the period of 1988 to 1989 . 

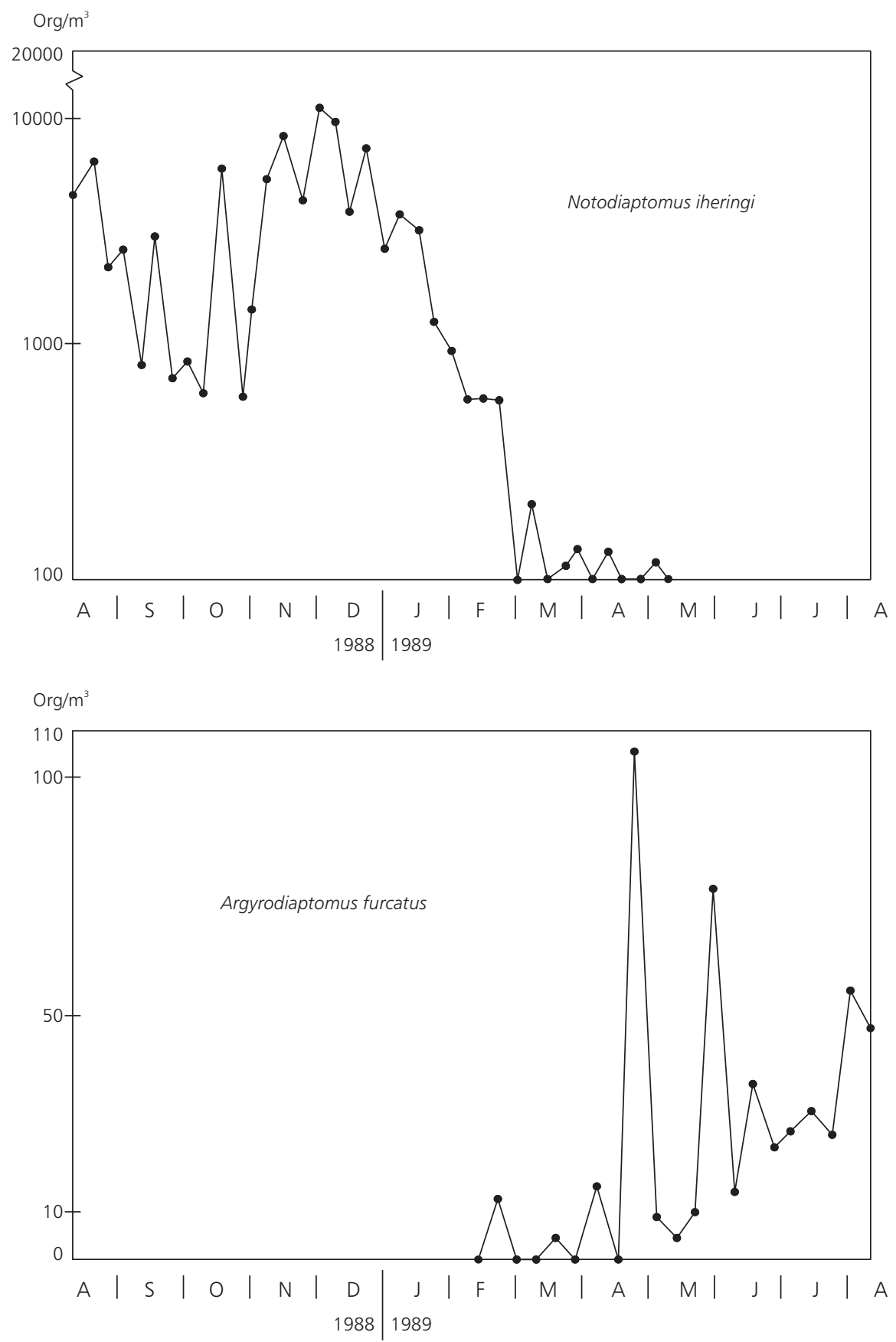

Fig. 5 - Monthly variation of adult populations of Argyrodiaptomus furcatus and Notodiaptomus iheringi through the period August 1988 to August 1989. 
Life cycle of Argyrodiaptomus furcatus and Notodiaptomus iheringi

Table 3 shows the developmental time of Argyrodiaptomus furcatus and Notodiaptomus iheringi obtained in the laboratory. A. furcatus showed significantly longer developmental time than $N$. iheringi for egg and naupliar stages at $17^{\circ} \mathrm{C}$ and for naupliar stages at $21^{\circ} \mathrm{C}$. At $26^{\circ} \mathrm{C}$, a longer developmental time of naupliar and copepodid stages of $A$. furcatus was observed.

The developmental time from egg to egg at 21 and $26^{\circ} \mathrm{C}$ corresponded to approximately 28 and 14 days for $N$. iheringi and 37 and 19 days in the case of A. furcatus. However, at lower temperatures, both species showed a slower developmental time.

Fecundity values (n. eggs/n. females) obtained for both species (Table 4), showed higher fecundity for Argyrodiaptomus furcatus at $21^{\circ} \mathrm{C}$ and $26^{\circ} \mathrm{C}$ (17.19 and 12.50 respectively). In the case of $N$. iheringi these values corresponded to 5.55 and 7.80 , respectively. A. furcatus showed also higher longevity (94 and 102 days) than $N$. iheringi (59 and 61 days) at both temperatures.

TABLE 3

Developmental time (days) of different stages of Argyrodiaptomus furcatus and Notodiaptomus iheringi at three temperatures $\left(17^{\circ} \mathrm{C}, 21^{\circ} \mathrm{C}\right.$ and $\left.26^{\circ} \mathrm{C}\right)$.

\begin{tabular}{|c|c|c|}
\hline Developmental time & Argyrodiaptomus furcatus & Notodiaptomus iheringi \\
\hline Stages & $17^{\circ} \mathrm{C}$ & $17^{\circ} \mathrm{C}$ \\
\hline Egg to nauplii I & 5.22 & 3.54 \\
\hline Nauplii I to copepodit I & 10.04 & 8.64 \\
\hline \multirow[t]{2}{*}{ Copepodit I to adult (female with eggs) } & & 24.18 \\
\hline & $21^{\circ} \mathrm{C}$ & $21^{\circ} \mathrm{C}$ \\
\hline Egg to nauplii I & 2.9 & 2.44 \\
\hline Nauplii I to copepodit I & 11.78 & 6.19 \\
\hline \multirow[t]{2}{*}{ Copepodit I to adult (female with eggs) } & 22.12 & 19.6 \\
\hline & $26^{\circ} \mathrm{C}$ & $26^{\circ} \mathrm{C}$ \\
\hline Egg to nauplii I & 1.56 & 1.26 \\
\hline Nauplii I to copepodit I & 4.96 & 3.12 \\
\hline Copepodit I to adult (female with eggs) & 12.5 & 9.51 \\
\hline
\end{tabular}

\section{TABLE 4}

Fecundity (average values) and longevity (days) data of Argyrodiaptomus furcatus and Notodiaptomus iheringi at three temperatures $\left(17^{\circ} \mathrm{C}, 21^{\circ} \mathrm{C}\right.$ and $\left.26^{\circ} \mathrm{C}\right)$.

\begin{tabular}{|c|c|c|c|c|}
\hline \multirow{2}{*}{ Temperature } & \multicolumn{2}{|c|}{ Argyrodiaptomus furcatus } & \multicolumn{2}{c|}{ Notodiaptomus iheringi } \\
\cline { 2 - 5 } & Fecundity & Longevity (days) & Fecundity & Longevity (days) \\
\hline $\mathbf{1 7}^{\circ} \mathbf{C}$ & & & & 51.31 \\
\hline $\mathbf{2 1}^{\circ} \mathbf{C}$ & 17.19 & 94.25 & 5.55 & 59.10 \\
\hline $\mathbf{2 6}^{\circ} \mathbf{C}$ & 12.50 & 102.00 & 7.80 & 61.61 \\
\hline
\end{tabular}




\section{Gut content analysis}

Table 5 shows the phytoplankton species found in the gut content of Argyrodiaptomus furcatus and its abundance. It represents a list of species found in 54 individuals examined. Aulacoseira spp., followed by Staurastrum spp., Cosmarium sp., Chlorococcales and Monoraphidium spp were the most ingested algae. In some individuals, mastax and lorica of rotifers were also found. Table 6 shows the phytoplankton species found in the gut content of Notodiaptomus iheringi and its abundance. This species consumed lesser phytoplankton species than A. furcatus. However, diatoms were also the most consumed algae. In both cases, the main food items ingested coincided with the major phytoplankton species found in the reservoir.

TABLE 5

Gut content of Argyrodiaptomus furcatus.

\begin{tabular}{|c|c|c|c|}
\hline \multirow{2}{*}{ Item } & \multicolumn{2}{|c|}{ Cells size } & \multirow{2}{*}{ Abundance } \\
\hline & Length (um) & Width (um) & \\
\hline \multicolumn{4}{|l|}{ Cyanophyta } \\
\hline Microcystis sp. & & 14.0 & + \\
\hline Peridinium sp. & 28.0 & 22.4 & + \\
\hline \multicolumn{4}{|l|}{ Chrysophyta } \\
\hline Dinobryon sp. & $42.0-53.0$ & $8.0-14.0$ & + \\
\hline Aulacoseira distans & $11.0-14.0$ & $5.6-11.2$ & +++ \\
\hline A. granulata & $22.4-64.0$ & $8.4-25.2$ & +++ \\
\hline A. italica & $22.0-32.0$ & $6.0-14.0$ & ++++ \\
\hline Nitzchia sp. & 42.0 & 2.8 & + \\
\hline Tetraedriella sp. & 15.0 & 11.0 & + \\
\hline \multicolumn{4}{|l|}{ Chlorophyta } \\
\hline Ankistrodesmus falcatus & 58.8 & 2.8 & + \\
\hline Chlorococcales & $5.6-8.4$ & $2.8-5.6$ & ++ \\
\hline Coelastrum reticulatum & $11.2-14.0$ & $11.2-14.0$ & ++ \\
\hline Cosmarium sp. & $8.4-14.0$ & $8.4-11.2$ & ++ \\
\hline Dictyosphaerium sp. & 8.0 & 6.0 & + \\
\hline Monoraphidium sp. & $11.0-84.0$ & $1.4-3.1$ & ++ \\
\hline Oocystis lacustris & $8.0-11.2$ & $5.6-8.0$ & + \\
\hline Scenedesmus sp. & 44.8 & 28 & + \\
\hline Staurastrum sp. & 19.6 & 16.8 & ++++ \\
\hline Staurodesmus sp. & 32.0 & 20.0 & + \\
\hline Tetraedron caudatum & $8.0-19.6$ & $11.0-19.6$ & + \\
\hline Phytoflagelates & - & - & + \\
\hline Bacterias & - & - & + \\
\hline Mastax of rotifers & - & - & ++ \\
\hline Keratella sp. (Rotifera) & - & - & + \\
\hline
\end{tabular}

++++ (> 5 cells $) ;+++(4-5$ cells $) ;++(2-3$ cells $) ;+(1$ cell $)$ 
TABLE 6

Gut content of Notodiaptomus iheringi.

\begin{tabular}{|l|c|c|c|}
\hline \multirow{2}{*}{\multicolumn{1}{|c|}{ Item }} & \multicolumn{2}{c|}{ Cell size } & \multirow{2}{*}{ Abundance } \\
\cline { 2 - 4 } & Length & Width & + \\
\hline Cyanophyta & & & \\
\hline Microcystis sp. & 16.8 & 14.0 & ++++ \\
\hline Chrysophyta & & & ++ \\
\hline Cyclotella spp.* & - & $14.0-22.4(\varnothing)$ & +++ \\
\hline Aulacoseira distans & - & $11.2(\varnothing)$ & +++ \\
\hline A. granulata** & $20.0-50.4$ & $2.8-9.8(\varnothing)$ & + \\
\hline A. granulata curvata & $11.2-58.8$ & 5.6 & ++ \\
\hline Nitzchia sp. & 23.0 & 9.2 & + \\
\hline Phytoflagelates & - & - & + \\
\hline
\end{tabular}

++++ (> 5 cells $) ;+++(4-5$ cells $) ;++(2-3$ cells $) ;+(1$ cell $)$

\section{DISCUSSION}

Reservoirs are very dynamic ecosystems in terms of structure and function, showing transient states in physical, chemical and biological conditions. The response of planktonic organisms to these states can be very sudden, as it is shown in the literature of reservoir ecology (Rocha et al., 1999; Straškraba, 1999).

The physical and chemical changes interfere with the dynamics of planktonic communities which respond with, changing behavior patterns, reproductive and physiological activities. Thus, the biological characteristics such as fecundity, birth, growth and mortality rates, migration and diapause are all influenced by environmental factors (Pennak, 1946; Vijverberg \& Richter, 1982; Threlkeld, 1986; Maier, 1989). It may also lead to structure and succession changes in the case of species having similar requirements.

By comparing life-cycle aspects of Argyrodiaptomus furcatus and Notodiaptomus iheringi, it was shown that relatively low temperatures were responsible for lower populational densities of both species during the winter.

This was demonstrated by the high mortality of copepodids and no reproduction of A.furcatus and $N$. iheringi at $17^{\circ} \mathrm{C}$, in the laboratory.

In general, the developmental time of $N$. ihering $i$ was faster than of $A$. furcatus. However, fertility and longevity were favourable for $A$. furcatus indicating it to be a better-adapted species at this reservoir, which has a relatively low retention time (20 and 84 days respectively, during rainfall and dry period).

A. furcatus is well adapted to the oligotrophic conditions of the reservoir as shown by adult feeding behaviour. A. furcatus ingested a varied diet consisting of diatoms and green algae with sizes varying from $<20 \mu \mathrm{m}$ to $>20 \mu \mathrm{m}$, indicating a wide feeding spectrum.

In the case of $N$. iheringi, besides the feeding overlap with A. furcatus, the food ingested was always smaller than $20 \mu \mathrm{m}$, indicating a less flexible food spectrum.

Probably these two organisms behave as opportunistic selectors of food available (De Mott, 1995) discriminating food of low quality when there is abundance of high quality food (Lehman, 1976).

The wider size spectrum of food ingested by A. furcatus can be an advantage in oligotrophic environments. The larger size of A. furcatus with small differences in the mouth appendages compared to $N$. iheringi and the feeding overlap also corroborate this hypothesis.

Lobo (Broa) reservoir is undergoing a process of eutrophication represented by changes in conductivity, dissolved inorganic nutrients and $\mathrm{pH}$. In several years of sampling prior to 1980, values 
of ammonium were less than $200 \mu \mathrm{g}$.litre ${ }^{-1}$ in the upper part of the reservoir where populations of A. furcatus were abundant (Rocha et al., 1982; Neuman Leitão et al., 1990). In the last two years (2000 and 2001) a steady increase of eutrophication has produced values of ammonium from 900 up to $1,400 \mathrm{mg}$. litre ${ }^{-1}$, mainly in the upper reaches of the reservoir (Abe et al., 2000; Espíndola, personal communication). At the present stage of eutrophication, $N$. ihering $i$ is again the dominant copepod species with the disappearance of $A$. furcatus.

The occurrence of these two species at Broa reservoir is marked by strong differences in density. $N$. iheringi can be dominant or even replace $A$. furcatus in eutrophic environments as is the case with Broa reservoir at its present trophic state. $A$. furcatus, the dominant species among the zooplankton species until 1988, was temporarily replaced by $N$. iheringi for about one year, a period when mining activities upstream was intense damaging the upper portion of the reservoir. From 1989 on, A. furcatus recovered its dominance, although recently $N$. ihering $i$ was found to represent a large percentage of the Calanoida populations, being nowadays, the only species found in the reservoir. At the same time, deterioration in water quality has been found, mainly due to domestic sewage.

Although both species can coexist in oligomesotrophic environments with higher spatial heterogeneity and residence time, as observed by Henry \& Nogueira (1999) in Jurumirim reservoir, they present differences in numerical density. It indicates a competitive mechanism between $N$. iheringi and A. furcatus (De Mott, 1989), being $N$. iheringi the dominant species.

The alternance pattern of density of Argyrodiaptomus furcatus and Notodiaptomus iheringi at Broa reservoir is a possible case of functional complementarities, where a certain environmental factor such as $\mathrm{pH}$, conductivity and temperature triggers planktonic composition with differences of tolerance by the species to various ranges of physical and chemical factors. The similarities in food ingestion observed, resulting in feeding overlap might have also contributed to the copepod population changes in the reservoir.

Broa reservoir has been subjected to inputs of anthropic activities, consequently to changes in water turbidity, conductivity and $\mathrm{pH}$. Each time there is a significant change of its limnological characteristics, one of the two species becomes predominant.

Argyrodiaptomus furcatus is known for its ability to live in low conductivity waters, with neutral to high $\mathrm{pH}$, high dissolved oxygen and low turbidity. Notodiaptomus iheringi occupies eutrophic reservoirs with high turbidity, higher conductivity and lower concentrations of dissolved oxygen. Both species produce resting eggs in the sediment, therefore it is possible that a permanent stock of ovigerous sacs of the two species remain in the sediment. However, with changes in the environmental conditions, one of the two species in the sediment is stimulated and predominates as planktonic population. Recent results confirm this hypothesis. Also, preliminary studies (Tundisi et $a l$. , in preparation) show that $N$. iheringi tolerates a wider range of conductivity than A. furcatus, being possibly important indicators of oligotrophic and eutrophic waters.

King et al. (1986) observed that $\mathrm{pH}$ elevation initiated the replacement of Tropodiaptomus spectabilis by Metadiaptomus transvaalensis in Lake Midmar, South Africa. Baily (1969) considered that the ionic proportions as well as conductivity are fundamental factors in the distribution of certain calanoid species

$$
\text { Moreover, the ratios of } \frac{\mathrm{HCO}_{3}^{-}+\mathrm{CO}_{3}^{--}}{\mathrm{Cl}^{-}} \text {and }
$$

$\frac{\mathrm{Na}^{+}+\mathrm{K}^{+}}{\mathrm{Ca}^{++}+\mathrm{Mg}^{++}}$seems to be decisive in the survival of freshwater species of copepod calanoids. These, altogether with differences in adaptive strategies of Argyrodiaptomus furcatus and Notodiaptomus iheringi, including life-cycle and feeding features, seem to be the cause for changes in the occurrence and population dynamics of $A$. furcatus and $N$. ihering $i$ at Broa reservoir.

Acknowledgments - The authors acknowledge the support of FAPESP (Process number 98/5091-2) for this work.

\section{REFERENCES}

ABE, D. S., ARANTES, J. D., MINOTI, R. T., PETRACO, P., SILVA, W. M. \& TUNDISI, J. G., 2000, O processo de eutrofização artificial na represa do Lobo (Itirapina$\mathrm{SP})$ : condições atuais e perspectivas futuras. Resumos, Seminário Internacional da Represa do Lobo-Broa (30 anos de pesquisa em Limnologia), p. 26. 
BAILY, I. A. E., 1969, The occurrence of calanoid copepods in Athalassia saline waters in relation to salinity and anionic proportions.Verh. Internat. Verein. Limnol., 17: 449-455.

De MOTT, W. R., 1989, The role of competition in zooplankton succession. In: U. Sommer (ed.), Plankton ecology: succession in plankton communities. Springer-Verlag, Berlin, cap. 6, pp. 195-252.

De MOTT, W. R., 1995, Effects of between lake variation in food abundance on the feeding behavior of calanoid copepods. Freshwat. Biol., 33: 171-180.

EDMONDSON, W. T., 1965, Reproductive rate of planktonic rotifers as related to food and temperature in nature. Ecol. Monogr., 35: 101-111.

GANNON, J. E. \& GANNON, S. A., 1974, Observations on the narcotization of crustacean zooplankton. Crustaceana, 28: $220-224$.

HENRY, R. \& NOGUEIRA, M. G., 1999, A Represa de Jurumirim (São Paulo): primeira síntese sobre o conhecimento limnológico e uma proposta preliminar de manejo ambiental. In: R. Henry (ed.), Ecologia de reservatórios: estrutura, função e aspectos sociais. Fundibio/Fapesp, pp. 653-685.

KING, E. M., RAYNER, N. A., GRIFFITHS, M. F.\& HEEG, J., 1986, Factors affecting the elimination of Tropodiaptomus spectabilis and its replacement by Metadiaptomus transvaalensis in an oligotrophic lake. Syllogeus, 58: 341-349.

LEHMAN, J. T., 1976, The filter feeder as an optimal forager, and the predicted shapes of feeding curves. Limnol. Oceanogr., 23: 1144-1154.

MAIER, G., 1989, The effect of temperature on the development times of egg, naupliar and copepodite stages of five species of cyclopoid copepods. Hydrobiologia, 184: 79-88.

MATSUMURA-TUNDISI, T. \& TUNDISI, J. G., 1976, Plankton studies in a lacustrine environment. 1. Preliminary data on zooplankton ecology of Broa Reservoir. Oecologia, 25: 265-270.

MATSUMURA-TUNDISI, T., RIETZLER, A. C. \& TUNDISI, J. G., 1989, Biomass (dry weight and carbon content) of plankton Crustacea from Broa reservoir (São Carlos, SP, Brazil) and its fluctuation across one year. Hydrobiologia, 179: 229-236.
NEUMAN LEITÃO, S., MATSUMURA-TUNDISI, T. \& CALIJURI, M. C., 1990, Distribuição e aspectos ecológicos do zooplâncton da represa do Lobo (Broa), São Paulo. Anais, IV Encontro Brasileiro de Plâncton, UFPE, Recife, pp. 393-411.

PENNAK, R. W., 1946, The dynamics of freshwater plankton populations. Ecol. Monogr., 16(4): 341-355.

RIETZLER, A. C., 1991, Estudo da dinâmica de populações de Copepoda-Calanoida na represa do Lobo (Broa). Dissertação de Mestrado, USP, 196p.

ROCHA, O. \& MATSUMURA-TUNDISI, T., 1984, Biomass and production of Argyrodiaptomus furcatus a tropical calanoid copepod in Broa reservoir, southern Brazil. Hydrobiologia, 113: 307.

ROCHA, O., MATSUMURA-TUNDISI, T. \& TUNDISI, J. G., 1982, Seasonal fluctuation of Argyrodiaptomus furcatus populations in Lobo Reservoir (São Carlos, SP, Brazil). Trop. Ecol., 23(1): 134-150.

ROCHA, O., MATSUMURA-TUNDISI, T., ESPÍNDOLA, E. L. G., ROCHE, K. F. \& RIETZLER, A. C., 1999, Ecological theory applied to reservoir zooplankton. In: J. G. Tundisi \& M. Straškraba (eds.), Theoretical reservoir ecology and its applications. Brazilian Academy of Science/ International Institute of Ecology/Backhuys Publishers, pp. 457-476.

STRAŠKRABA, M., 1999, Self-organization, direct and indirect effects. In: J. G. Tundisi \& M. Straškraba (eds.), Theoretical reservoir ecology and its applications. Brazilian Academy of Science/International Institute of Ecology/Backhuys Publishers, pp. 29-51.

TUNDISI, J. G. \& MATSUMURA-TUNDISI, T., 1995, The Lobo-Broa ecosystem research. In: J. G. Tundisi, C. E. M. Bicudo \& T. Matsumura-Tundisi (eds.), Limnology in Brazil, ABC/SBL Publisher, Rio de Janeiro, 376p.

THRELKELD, S. T., 1986, Life table responses and population dynamics of four cladoceran zooplankton during a reservoir flood. J. Plankton Res., 8(40): 639-647.

VIJVERBERG, J. \& RICHTER, A. F., 1982, Population dynamics and production of Daphnia hyalina Leydig and Daphnia cucullata Sars in Tjeukemeer. Hydrobiologia, 95: 235-259. 